\title{
Micropolitics of Urban Slums: Variations in How the Urban Poor Organize Politically
}

\author{
Stephen Armet $^{\mathrm{a}}$
}

\begin{abstract}
What social factors influence political participation among the urban poor in Latin America? This paper engages conventional theories of political action pertaining to the urban poor characterized by analytical cleavages that have traditionally accounted for the majority of variation in political behavior. Using primary survey data from La Carpio slum of San José, Costa Rica, multivariate regression analyses show that differing social factors influence political participation in dissimilar ways. Because La Carpio slum respondents moderately participate in community-based organizations and civil protest, nor are they manipulated by clientism, a theory of "quiet encroachment" may serve as an alternative framework for understanding the political behavior of respondents who seek to ameliorate harsh urban realities which have not improved in spite of a move to the center-left by transitional political movements in Latin America.
\end{abstract}

\section{Keywords}

Urban poor, quiet encroachment, clientism, neighborhood associations

According to Philip Oxhorn (2009), many Latin American societies are experiencing a paradox after thirty-plus years of neoliberal development. Politically, most Latin American nations are more democratic than any time in their history and people enjoy unprecedented opportunities to exercise a meaningful political voice. At the same time, neoliberalism has failed to generate high levels of sustained economic growth, in spite of curbing inflation, resulting in greater socio-economic exclusion and absolute poverty. In a shifting economic and political ecology of Latin America, one research question that has continually engaged social science concerns the relationship between the poor and the state. This paper builds on and contributes to a considerable extant body of research on political behavior of the urban poor by asking subjects to self-identify and quantify their own political behavior. This project asks: "how do residents of La Carpio slum of San José, Costa
Rica participate in political action and what motivates their behavior?". By answering this question, this paper will: (1) highlight the dissimilarity of social factors predicting political engagement; and (2) ascertain if urban poor subjects behave politically in ambiguous ways outside of conventional analysis. This analysis adds value to the solid existing body of literature by suggesting that informal patterns of micropolitics and resistance are legitimate forms of political engagement that are frequently overlooked by dominant analytical categories used to interpret political behavior of urban poor subjects.

The significance of political behavior by the urban

aUniversity of Notre Dame, USA

\section{Correspondent Author:}

Stephen Armet, PROLADES, 16733 Saratoga Ct., Granger, IN 46530, USA 
poor is an important question in light of shifts in the political and economic context since the 1980s. Most countries in Latin America - to varying degrees - experienced a deviation of authoritarianism which gave way to neoliberalism and democratic transitions. More recently, some societies (Venezuela, Bolivia, Argentina, Chile, Uruguay, and Ecuador) have moved to the centre-left in order to constrain the effects of neoliberalism. In spite of political and economic transformations, has anything been changed regarding how the urban poor engage politically? Several Latin American scholars have developed the concept of "citizenship" as both a benchmark and a framework by which to interpret democracies in transition-yet are the poor preoccupied with notions of citizenship (Roberts 2005; Oxhorn 2003; 2011; Tulchin and Ruthenburg 2007)? If citizenship is conceptualized as "consumption" then the poor will continue to be marginalized (Echegaray 2015; Oxhorn 2010). Citizenship as "agency" may be achievable since political engagement is associated with participatory institutions, such as community-based organizations, which are accessible and serviceable to the poor. However, do the poor really rely on conventional distributional mechanisms within the state apparatus or do they rely on everyday practices integrated into a coherent worldview resulting in politics of informality ${ }^{1}$ ?

\section{PREVIOUS RESEARCH: WHAT WE ALREADY KNOW}

What we know so far about the political engagement of the urban poor in Latin America has been shaped by a long tradition of research producing a solid basis of understanding regarding how this process works. Several analytical cleavages have emerged coalesced around specific theoretical arguments. Given the effects of neoliberalism over the last 35 years resulting in austerity measures, loss of employment due to privatization, reduction in public spending due to debt service, reversal of capital flow, exacerbation of economic deprivation and inequality, one would expect the urban poor to resort to contentious social protest in response. This has led some researchers to assume that the principal agents involved in political protest are shantytown residents who stage mass demonstrations and resort to looting when rallies are disrupted by police (Walton 1998; 2001). While Castells' (1977) urban radicalism thesis could not be validated empirically, new forms of radicalism emerged generating some support for a radical paradigm (Schneider 1995; Stokes 1991; 1995). Although passivity in the absolute sense is an invalid assessment, there is ample support for more conservative forms of political expression (Portes 1972; Gilbert 1998; Eckstein 2001). Historically, conservatism among the poor can be attributed to the daily demands of survival, domestic demands, a distaste for confrontation, gender expectations, or a repressive environment ${ }^{2}$. However, political conservatism is not necessarily equated with a political behavior; rather it is explained by various forms of clientism, patronage, and associational life. A repertoire that was once conditioned by a radical/passive tension now includes varying political arrangements, new forms of contestation, and modes of organization thus warranting a reassessment of the poor's political repertoire, especially in light of Latin America's shifting political and economic ecology ${ }^{3}$.

Clientism has been found to be one of the most prominent and enduring features (Ruth 2016) in the political landscapes in the favelas of Brazil (Cardoso 1992; Gay 1994), the pueblos jóvenes of Peru (Stokes 1995; Dietz 1998), the ranchitos of Quito (Lind 2005; Dosh 2006; Burgwal 1995), las invasiones of Colombia (Gilbert and Ward 1984; Gilbert 1998), and las colonias of Mexico (Barriga 1996; Eckstein 1990). An optimistic view would suggest that it provides a mechanism of exchange and solidarity in asymmetrical power relationships between elites and masses (Gay 1994: 5-6). Although clientism involves 
informal face-to-face relationships, the process is at various stages of institutionalization throughout Latin American slums (Walton 1998: 461; Burgwal 1995: 13-15). Yet its outcomes are mixed if not ambiguous. Gay's (1994: 141-145) comparative analysis of two favelas in Rio de Janeiro found that while the Vila Brazil slum depended on clientistic patronage to produce immediate and dramatic results, the Vidigal slum achieved similar results due to the strength of its neighborhood association to negotiate directly with various government agencies to make improvements. In squatter settlements of Quito, Burgwal (1995: 221-229) attempted to understand the relationship between neighborhood associations and clientism and concluded that the mixed results of clientism were attributed to the interaction of a multiple of dyads such as association leaders and the rank and file members, squatters and the state, adversarial and sympathizing external agents, and patrons and clients. In possibly the most comprehensive evaluation of political behavior, Dietz (1998: 133) conducted a longitudinal comparative analysis of six slum areas across Lima that measured participatory political behavior and concluded that economic well-being more than political ideology motivated slum residents to engage politically and that they did not care which party delivered it. Street vendors in Mexico City found that clientistic relations could be used to thwart or reverse governmental attempts to eliminate the informal economy (Cross 1998). In Porto Alegre, clientism among the Brazilian Worker's Party (Partido dos Trabalhadores, PT) was associated with low levels of popular participation (Rhodes 2003). Offering an equally pessimistic view, Cardoso (1992: 301) concluded that clientism among the poor was chaotic, unpredictable and the gains it may produce were reversible. Lastly, the reemergence of neo-leftists regimes may be less vulnerable to clientism than before. The neo-left's moderation on radical change that made them competitive has also quieted their voice that spoke for wider political participation and greater social equality (Petras 1999). Mainwaring and Scully (1995) had noted that while poverty and inequality remain more pressing issues than ever, they are less effectively voiced on behalf of the poor.

Because clientism is predicated upon associational life, several studies have focused on the significance of neighborhood associations. Community-action programmes in Latin American slums have a tradition dating back to the 1950 s as a means to integrate the poor into society and promote democracy (Gilbert and Ward 1984). Neighborhood associations have been a principal mechanism for demand-making amongst urban poor societies (Friedmann 1989; Cross 1998; Mitlin 2001; Palmer 2003). While associations can be a contingency for clientism, patronage is not the inevitable outcome as community groups can negotiate directly with government representatives. While some researchers appear to romanticize neighborhood associations by over-emphasizing their role in the emergence of civil society, others are less optimistic $^{4}$. For example, disputes frequently undermine consensus that can result in competing associations (Stokes 1995; Burgwal 1995; Dietz 1998; Cardoso 1992; Mitlin 2001). Neighborhood associations are characteristically demanded and short term oriented, implying that once the demand is met, they disband (Neuhouser 1995; Mainwaring 1987). Gilbert and Ward (1984) concluded that local associations are instruments of social control and hierarchical forms of manipulation by means of legitimating the political system, a structure of garnering votes and ensuring compliance with urban political decision-making. Mainwaring's (1989) analysis of popular movements built around neighborhood associations in Brazil found that associations were characterized by fragmentation with few effective linkages; local participation was the exception rather than the norm, and that democratization led to increased competition rather than cooperation among associations. In addition, 
whether or not neighborhood associations are local and autochthonous expressions of collective demand-making is called into question. Burgwal (1995) found that associations in the slums of Quito are frequently influenced by outside sources and external sponsors which provide much of the resources, information, and even discourse for neighborhood associations resulting in dependency on external agents. As the activities of NGOs and Transnational NGOs (TNGOs) increase, it is difficult to imagine professional middle class leadership doing anything less than colonizing neighborhood associations of the poor. Schild $(1998 ; 2002)$ found that many poor women in Chile resented the imposition of feminist programmes designed by middle-class professional women employed by NGOs. Bayat (2000) observed that NGOs working in the Middle East tended to diminish the local mobilization of grassroots activism while at the same time established new forms of clientism and competition between local associations vying for benefits of international organizations. Chalmers, Martin, and Piester (1997) had identified a new medium for locally generated, bottom-up initiatives, centered around "associative networks" that have effectively supplanted or replaced political parties as vehicles for demand-making on the political system. Likewise, Lind (2005) found that an unintended consequence of associations in Ecuador is that they effectively redistributed the social responsibility and management of social welfare from the state to private sectors. While circumventing traditional clientism/patronage arrangements, however, new associative networks are frequently dependent on foreign NGOs which not only make the grassroots founders a "client group", but also cast doubts on the sustainability and self-determination of such community-based associations ${ }^{5}$.

While clientism and patronage have been found to be the most universal linkage between the urban poor and the state, radical activism in Latin America has tended to be identified with the poor. For example, Schneider (1988) found that among Chilean shantytown residents, resistance and protest to Pinochet's authoritarian regime was strongest in those poblaciones where the Communist Party (PC) was most active and advocated for popular insurrection. Uniquely radical and uniquely quiet-albeit an efficacious anti-regime response-was the arpilleras or "solidarity art" created by women coping with poverty and fear of repression in Chilean shantytowns (Adams 2012; 2013). Radical activism frequently has taken the form of street protests and civil unrest in response to austerity policies associated with neoliberalism. Because collective consumption is considered to be the most common motive for overt acts of public protest, a common assumption is that the largest category of participants are residents of the slums, who stage mass demonstrations and resort to violence and looting when repressed by police (Walton and Ragin 1990; Walton 2001; 1998). However, recent research does not support this view. Several researchers identify the sources of public protest to originate in the middle class barrios led by public employees, teachers, police, and small shop owners (Auyero 2001; Villalón 2007; Köhler and Wissen 2003; Garay 2007; Almeida 2007). The severe economic crisis in Argentina (1998-2002) gave rise to numerous alternative and innovative expressions of dissent and contentious protests, yet most of these public forms of protest are associated with the middle and working class (Blackwell 2002; Foweraker and Landman 1997; Villalón 2007; Auyero 2001). In fact, regarding the heterogeneity of one protest in Buenos Aires, a researcher commented that the protest included "shanty town dwellers with missing teeth, people who did not even know what to do" (Blackwell 2002). McAdam and associates (2005) had observed that most public protests are initiated by the advantaged. Researchers who have attempted to explain why urban poor subjects generally abstain from public protest attribute the cause to logistics; the 
urban poor do not have time. They spend long hours getting to and returning from work. The exhausting nature of daily life by itself represents an obstacle to participation (Castells 1983; Mainwaring 1989; Gilbert 1998).

\section{GAPS IN THE CURRENT RESEARCH}

All together this body of research has produced findings that enable researchers to state, with confidence, certain conclusions that are reliable estimates of how the poor engage in political behavior. We know that variation in political behavior among the urban poor is influenced by contextual factors such as regime type, policies of the state towards civil society, the intensity of poverty, the availability of local leadership, and sympathizing external agents among others. However, extant literature, as valuable as it is, reflects certain limitations worth noting. First, several studies have made the subject of their research the working class, rather than those in absolute poverty. While some studies explicitly state that the barrio or invasion consists of working class subjects (Foweraker and Landman 1997; Dietz 1998), others appear to assume that participants in a land invasion or residents of favelas and ranchitos are in fact the lowest class of society (Stokes 1995; 1991; Burgwal 1995); however, even urban slums can be socially stratified (Ward 2005). This is an important distinction in poverty studies because subtle changes in social stratification can affect opportunities and life strategies. Second, studies that correspond to traditional political cleavages assume that "collective consumption" is the principal motivation that explains political behavior of the urban poor ${ }^{6}$. These studies take for granted that urban poor subjects have reasoning powers to resist clientistic manipulation and frequently associate material advancement with their own sense of social justice and moral imperative (Armet 2005). Research on Latin America tends to fall on the divide between political/economic interests or social/religious interests. There is a dearth of research available that examines the life of the urban poor holistically (Ortner 1995). This includes religion which is a rich repository of cultural beliefs and values and often has close affinities with resistance/survival strategies. Third, although a case has been made that traditional clientism is the most common form of political engagement, there is evidence that the nature of the relationship between clientism and neighborhood associations is undergoing change due to transformations precipitated by neoliberalism and the growing role of NGOs. In some cases, neoliberalism has become entrenched while in other cases, neoliberalism has been challenged by center-left administrations. Regardless of the political tilt of the regime, some researchers suggest that neoliberalism has created an indelible imprint on the political economy of Latin American nations that cannot be easily reversed (Weyland 2004a; 2004b). One outcome is that incumbents are increasingly concerned about market and economic performance such that re-election will depend less on political alliances making politicians less vulnerable to clientistic pressures (Colburn 2002). If this is true, then researchers need to explore whether or not patronage and clientism is still functional in slum areas as it had in the past. Last, even though public protests have become more innovative and heterogeneous due to the extreme economic inequality associated with neoliberal policies, the urban poor rarely and sporadically participate in contentious politics. The emphasis on the emancipatory potential of grassroots initiatives may have been over exaggerated by social movement theorists who believed that many urban movements would deepen democracy $^{7}$. While resistance is a part of the repertoire of the urban poor, resistance is only half of the story. The poor are more interested in making progress and improving their lives, as slow as it may be. How can they improve their lives outside of a conventional political framework allowed by the 
state's apparatus? While established analytical cleavages tell much of the story regarding the political behavior of the urban poor, is there unaccounted variation?

This study attempts to build on an existing body of research and findings, making contributions in some areas while acknowledging its own limitations, by conducting empirical research in La Carpio slum, identified as District 107, Uruca in the Cantón of Central San José, in San José Province. Compared to other urban squatter settlements referenced in this study, La Carpio is unique in several regards considering that in the post war era, Costa Rica was never under an authoritarian regime. As one of Latin America's oldest and most stable democracies, the source of Costa Rica's financial dependency to the IMF (International Monetary Fund) and World Bank has been due to financing its welfare state. Since the debt crisis of the early 1980s, heavy borrowing pushed the country along the structural adjustment path of trade liberalization, privatization, and the erosion of the welfare state (Rottenberg 1993; Green 1999). Although politically unique, Costa Rica's experience with neoliberalism is consistent with other Latin American societies such that outside of reducing inflation (which does help the poor), it has failed to produce strong economic growth or decrease poverty and inequality.

\section{BACKGROUND OF LA CARPIO}

The largest slum of San José, La Carpio was principally achieved by family units invading open spaces "gradually" rather than "violently" as politically motivated massive land invasions have never been documented in San José as they are in other urban areas in Latin America ${ }^{8}$. The first official household registry occurred in 1999 by the Instituto Mixto de Ayuda Social (Mixed Institute for Social Service, IMAS) which identified 2,518 households. The 2000 census by El Instituto Nacional de
Estadística y Censos (National Institute of Statistics and Census, INEC) counted 2,742 households while the Ministerio de Vivienda y Asentamientos Humanos (Ministry of Housing and Human Settlements, MIVAH) registered 4,150 households in 2004 indicating either a disparity in government data collection or tremendous growth (Campos Cordero 2006). Suggesting the later, health authorities with the Area de Salud (Area of Health) estimated 15,083 residents in 2002 and 22,296 in 2004 (Sandoval García 2010). Poverty has remained around 20\%-25\% for nearly 20 years (Nemirovsky 2008) ${ }^{9}$. Government figures show that in 2003, $42 \%$ of the residents of $\mathrm{La}$ Carpio lived in absolute poverty, indicated by an inability to meet basic human needs. According to IMAS, the monthly income for the majority of the households in La Carpio in 2003 was between US\$ 258-323. Like most Latin America countries, the poverty rate is based upon the "basic grocery basket" (canasta básica mensual) containing enough nutrition to sustain a person for a month. In 2003, the INEC set this amount at US\$ 53 per person. The average household size in La Carpio was 4.9 yet 1,072 households (42\%) earned less than US\$ 258 a month. Another $46 \%$ lived in poverty although, according to government designations, they were able to meet their basic human needs.

\section{DATA AND METHODS}

Data used in this study were derived by random household surveys of the La Carpio slum area located to the northwest and approximately 20 kilometers from downtown San José, Costa Rica. This cross-sectional household survey was conducted between July 12 and August 1, 2011 by PROLADES (Programa Latinoamericano de Estudios Socioreligiosos, Latin American Socio-Religious Studies Program) — an educational and research institute located in San José, Costa Rica with a long history of conducting socio-religious research in Latin 
America. The survey was designed to explore housing, economic, social, and political attitudes and behaviors of La Carpio's residents. Field work was conducted by former enumerators of the National Institute of Statistics and Census and under the superintendence of PROLADES. The Costa Rican 2011 Census had just been undertaken-May 30 to June 3, 2011-by the INEC which employed 35,000 enumerators to implement the household questionnaire. The household surveys for this study were conducted by former enumerators who had been responsible for canvassing the La Carpio slum for the national census and were familiar with the social and ecological context. Given the lack of spatial coherency and the need to ensure randomization of households, every sixth household to the left of their first random contact was selected. Of the 448 households contacted, there were 78 refusals making a response rate for the survey of $82.5 \%$, thus producing 370 completed surveys and representative of the 30,000 residents who live in $\mathrm{La}$ Carpio. The data recorded in this survey rely on self-identification variables reported by adults over the age of 18 .

\section{DEPENDENT VARIABLES}

The unit of analysis in this paper is collective behavior which could be considered socio-political and engaged in with the hope of ameliorating hardships and providing a positive socio-economic outcome (by "socio-political", the author means not only obvious political expression such as voting or protest, but also participation in associations; be they informal and grassroots oriented or be they formal such as a trade union or political party). The dependent variables include: (1) the most fundamental forms of associational participation found in urban poor neighborhoods based on previous research; (2) voting; and (3) the most fundamental forms of protest in which urban poor residents typically participate. The survey asked all respondents about their experience and participation in associational life, voting, and civil protest (civil protest refers to the public articulation of a grievance by more than one person in which tactics generally include: rallies, demonstrations, marches, worker's strike, civil disobedience, riots, or mob violence), including the following: (1) "Do you or someone in your household have experience participating in one of the following types of associations? Neighborhood association, mutual assistance, community organization, political party, trade union, or no experience at all?"; (2) "Have you voted in the last two elections?"; and (3) "Have you or someone in your household ever participated in one of the following types of public protests? Public demonstration (march, rally, civil disobedience), civil unrest (riot), strike, or no experience at all?". From these three variables - associational life, voting, and civil protest - dichotomous dependent variables were constructed for this analysis indicating whether the respondent had experienced and participated in at least one of the stated socio-political activities or not.

\section{INDEPENDENT VARIABLES}

The survey analyzed in this study included a number of questions useful for analysis as independent variables which have been divided into three explanatory groups. The first set of independent variables correspond to predispositions and conditions antecedent to broader community involvement, including the following: (1) "Have neighborhood leaders attempted to organize the community for the purpose of social improvement or to press a demand?"; (2) "How did you respond to the neighborhood convocation? Negatively or Positively?"; (3) "How did the leaders of the community association function in your neighborhood? Despotically or Democratically?"; (4) "Have you ever been associated with other workers in the informal economy to protect your work zone and clients?"; and (5) "Which method have you utilized in order to legalize the title of your 
property tenure? Neighborhood collective approached the state office or I approached the state office directly?". A second set of variables distinguish among participation in varying forms of associations available to residents in La Carpio based on the availability of extant communal-based organizations confirmed by related scholarly works ${ }^{10}$. Respondents were asked: (6) "Has anyone in your household been the beneficiary of a social organization?". Responses included: "Community kitchen, community association, private organization (NGOs), state sponsored organization, social workers, or Church related association?". Because economic survival of the poor depends on adaptive strategies, such as the use of reciprocal kin relations specifically and social capital in general, the following question was incorporated into the analysis (Lomnitz 1974: 7): "In case of a crisis or emergency, from whom do you usually seek help? Family members, neighbors and friends, Church members, others?". A third set of variables in the data are used to represent attitudes and experiences of respondents in relation to varying degree of interface with the state, and these include the following: (8) "Has a politician come to your neighborhood making promises in order to gain your vote?"; (9) "Have you or someone in your household approached a state office in order to present a demand?"; (10) "Do you have confidence that politicians can improve conditions in your neighborhood?"; (11) Do you believe that state offices can improve the quality of life in your neighborhood?"; (12) "Has a member of your household been harassed by authorities for working in the informal economy?"; and (13) "Would you call the local police in the advent of an emergency?".

\section{CONTROL VARIABLES}

Lastly, because there is reason to believe that associational life, voting, and civil protest may be correlated with factors other than predispositions and experiences with socio-political collectivities, the analysis below controls for a number of demographic variables including: gender, age, head of household status, education, and duration as a resident of $\mathrm{La}$ Carpio. Most residents in $\mathrm{La}$ Carpio live in self-constructed housing in which they occupy the land, have "pirated" water and electricity from public sources, and engage in the informal economy thus demonstrating what Bayat (1997b) referred to as "direct action" and the "politics of informal people" vis-à-vis conformity to conventional means of housing and labor. Because this strategy can be interpreted as an attempt to remain autonomous from the state, it may be useful for our analysis to control for this tendency which would be assumed to moderate involvement in conventional political expressions. The survey asked all respondents this question: "According to your experience, which option do you consider to offer real and concrete solutions to the needs of your household?". Responses included: "State offices that offer social services, private organizations that offer social services, your own direct action". Collectively, these control variables enable the isolation of possible dispositional and experimental influences net of other possibly correlated variables.

\section{ANALYTICAL STRATEGY AND RESULTS}

Means and standard deviations of all variables are reported in Table 1. Since the independent variables are expressed as dummy variables, their means are proportions and reference variables, where appropriate, are noted. Because each of the three dependent variables is dichotomous, logistic regression is used to test for the effects of a number of independent variables simultaneously on the probability of respondents engaging in socio-political activities with the hope of ameliorating hardships and providing a positive social outcome. Table 2 presents the odds coefficients and significance of the association for three independent 
Table 1. Descriptive Statistics for All Variables Used in Logistic Regression

\begin{tabular}{|c|c|c|c|}
\hline Effect & Description & Mean & Std. Dev. \\
\hline \multicolumn{4}{|l|}{ Dependent variables } \\
\hline Collective association & $\begin{array}{l}\text { Participate in neighborhood association, mutual assistance } \\
\text { society, community organization, etc. }\end{array}$ & .16 & .36 \\
\hline Voting behavior & Voted in last two elections & .42 & .49 \\
\hline Civil protest & $\begin{array}{l}\text { Participate in public demonstration, march, rally, civil unrest, } \\
\text { workers strike, etc. }\end{array}$ & .15 & .36 \\
\hline \multicolumn{4}{|l|}{ Indepednent variables } \\
\hline Organize barrio & Attempts made to organize neighborhood & .71 & .45 \\
\hline Response to convocation & Positively regarded efforts to organize barrio & .35 & .47 \\
\hline Leadership (ref. = despotic) & Democratic leadership style of community organization & .59 & .49 \\
\hline Protect turf & Join informal workers group to protect turf & .03 & .17 \\
\hline Title (ref. = individually) & Collective attempt to legalize property & .59 & .49 \\
\hline Community kitchen & Benefits from community kitchen & .11 & .31 \\
\hline Community association & Benefits from community association & .07 & .26 \\
\hline Private/public assist. & Benefits from a NGO or state entity & .09 & .29 \\
\hline Social worker & Benefits from a social worker & .52 & .49 \\
\hline Church assistance (ref.) & Benefits from a church group & .45 & .49 \\
\hline Family network & Emergency network - family members & .58 & .49 \\
\hline Church network & Emergency network - church members & .27 & .44 \\
\hline Friends network (ref.) & Emergency network - friends & .13 & .34 \\
\hline Politician came to barrio & A politician campaigned in barrio making promises for your vote & .62 & .48 \\
\hline Approached state & Approached state directly with a demand & .40 & .49 \\
\hline Confidence in politician & Have confidence that politicians can help & .20 & .39 \\
\hline Confidence in the state & Have confidence that state ministries can help & .41 & .49 \\
\hline Harassed by authorities & Informal work having been harassed by authorities & .19 & .39 \\
\hline Trust in police & Have trust in the police & .32 & .46 \\
\hline \multicolumn{4}{|l|}{ Control variables } \\
\hline Gender & Male $=0 ;$ female $=1$ & .51 & .50 \\
\hline Age & $18-29$ to 65 or more by 10 -year increments & 2.5 & .988 \\
\hline Head of household & No $=0 ;$ yes $=1$ & .82 & .38 \\
\hline Education & $0=$ none to $7=$ university complete & 2.46 & 1.31 \\
\hline Duration in La Carpio & Years lived in La Carpio (1-20 years) & 11.4 & 4.6 \\
\hline Direct action & Offers concrete solutions to household's needs & .90 & .30 \\
\hline Private organizations & Offer concrete solutions to household's needs & .03 & .18 \\
\hline State offices (reference) & Offer concrete solutions to household's needs & .06 & .25 \\
\hline
\end{tabular}

analyses. Variance Inflation Factors (VIFs) were generated to check for collinearity among independent variables. No VIF exceeded 1.4, indicating that collinearity was not a cause for concern (Menard 1995).

Here, the author interprets results of the odds coefficients as each analysis provides an interesting 
Table 2. Coefficients From Logistic Regression Predicting Socio-Political Engagement

\begin{tabular}{|c|c|c|c|}
\hline Effect & $\begin{array}{l}\text { Associational } \\
\text { involvement }\end{array}$ & Voting behavior & Civil protest participation \\
\hline Collective association & ----- & $1.554^{* * *}$ & $2.596^{* * *}$ \\
\hline Voting behavior & $1.499^{* * *}$ & ----- & -.593 \\
\hline Civil protest & $3.087^{* * *}$ & $-.826^{*}$ & ----- \\
\hline Organize barrio & $1.543^{* *}$ & .121 & -.126 \\
\hline Response to convocation & $1.593^{* * *}$ & -.507 & $-.923^{*}$ \\
\hline Democratic leadership style a & $-.776+$ & -.121 & -.274 \\
\hline Protect turf & $2.580^{* *}$ & .072 & -.451 \\
\hline Communal title effort b & -.606 & -.254 & .570 \\
\hline Community kitchen ${ }^{c}$ & $-1.060+$ & -.164 & $1.872^{* * *}$ \\
\hline Community association ${ }^{c}$ & $1.828^{* *}$ & .221 & $-1.591^{*}$ \\
\hline Private/public assistance c & -.576 & $1.408^{* * *}$ & .126 \\
\hline Social worker ${ }^{c}$ & $.684+$ & -.409 & -.257 \\
\hline Family network ${ }^{\mathrm{d}}$ & 1.123 & .030 & -.451 \\
\hline Church network ${ }^{\mathrm{d}}$ & $1.948^{* *}$ & -.452 & $-1.201^{*}$ \\
\hline Politician came to barrio & $-.900^{* *}$ & $1.883^{* * *}$ & .462 \\
\hline Approached state directly & .047 & .363 & $1.267^{* * *}$ \\
\hline Confidence in politicians & $-.828+$ & $.926^{* *}$ & .199 \\
\hline Confidence in state offices & -.299 & $.606^{* *}$ & $-.870^{*}$ \\
\hline Harassed by authorities & .447 & $-.763^{*}$ & -.376 \\
\hline Trust in police & $.964^{* *}$ & -.149 & -.327 \\
\hline Gender (female) & .335 & -.404 & -.054 \\
\hline Age & -.079 & -.053 & $-.352+$ \\
\hline Head of household & -.434 & 554 & .158 \\
\hline Education & .104 & .120 & -.209 \\
\hline Duration in La Carpio & -.046 & .011 & -.035 \\
\hline Direct action to solve needs e & $-1.514^{*}$ & -.429 & .513 \\
\hline Rely on state to solve needs e & -.709 & -.925 & .553 \\
\hline Pseudo-R² (Cox \& Snell) & .273 & .268 & .219 \\
\hline Constant & $-3.724^{* *}$ & $-2.283^{* *}$ & -.779 \\
\hline - 2 log likelihood & 206.632 & 387.293 & 226.584 \\
\hline $\mathrm{N}$ for analysis & 370 & 370 & 370 \\
\hline
\end{tabular}

Notes: Data Source: La Carpio Survey (2011).

$+p<.10 ;{ }^{*} p<.05 ;{ }^{* *} p<.01 ;{ }^{* * *} p<.001$ (two-tailed test).

The reference categories are as follows: a Despotic leadership style; ${ }^{b}$ Individual effort to obtain title; c Social benefits from a church group; d Friend's network; ${ }^{e}$ Rely on NGOs to resolve needs. 
outcome. Net of other factors, respondents who have participated in some types of collective association are more than four times likely to have voted in the last two elections $(\exp [1.554]=4.731)$ than those who did not participate in an association and are 13 times more likely to engage in public protest $(\exp [2.596]=$ 13.413). Individuals voting in the last two elections are four times more likely to engage in a collective association than those who did not vote $(\exp [1.499]=$ 4.437), although voting reduces the odds of joining a civil protest by $45 \%$ relative to those who did not vote $(\exp [-.593]=.553)$. Likewise, respondents who have joined a civil protest are significantly more likely to also engage in a collective association however, they are less likely to vote. Residents of La Carpio who recognize attempts made by neighbors to organize a community association are four times more likely to join a collective association than those who live in a neighborhood where such efforts either do not take place or are unrecognized $(\exp [1.543]=4.677)$. As would be expected, respondents who respond positively to neighborhood convocations to organize significantly increase the odds of participating in a collective association but are significantly less likely to protest publicly. Curiously, those who believe that the leadership of neighborhood associations operates democratically are less likely to engage in any of the political activities measured than those who label the leadership despotic. Although a small group, individuals who have collaborated with other informal workers to protect their territory from authorities who might pose a threat were significantly more likely to join a collective association even though they would be less likely to join a public protest. Surprisingly, participating in a collective attempt to legalize land tenure in La Carpio slum decreases the odds of participating in a collective association and voting compared to those who attempted legalization on their own ${ }^{11}$. Receiving benefits from a community kitchen decreases the odds of both collective association involvement and voting although it significantly predicts that the odds of engaging in public protest is six times greater than those who derive no benefits $(\exp [1.872]=6.499)$. Predictably, receiving a benefit from a community association significantly increases the odds participating in a collective organization even though it decreases the odds of engaging in public protest. Recipients of assistance from either a private or public organization are significantly more likely to have voted in the last two elections compared to those who derive a social benefit from their church affiliation while benefits derived from contact with a social worker had negligible effects. Relative to a friend and neighbors' emergency network, respondents who indicated that their principal support network in times of crisis is their church network of relationships were significantly more likely to engage in a collective association although were less likely to participate in civil protest. Predictably, having a politician visited the respondent's barrio significantly increased the likelihood that they would vote by $557 \%$ $(\exp [1.883]=6.573)$. Individuals who have approached a state office or ministry with their demands directly significantly increased the odds of participating in a form of public protest. Confidence that politicians and state ministries can ameliorate the hardships of poverty significantly predicted voting in the last two elections but decreased the odds of joining a collective association. Informal workers having been harassed by authorities only moderately decreases the odds of voting while maintaining a favorable view of the police predicts a significant likelihood that respondents are engaged with a collective organization. Among control variables, direct action is of note. In comparison to social services provided by private NGOs, respondents who trusted in their own direct action were significantly less likely to find help in collective associations, although the effect on voting and joining a civil protest were negligible. 


\section{CONCLUSIONS}

An important empirical finding of this analysis is that different social factors influence how La Carpio's poor engage politically in dissimilar ways. Whether or not a respondent has benefited from a community kitchen or an NGO does not influence all types of political engagement alike; nor does confessing confidence in state ministries to ameliorate harsh social conditions. That said, results from the empirical analyses show that controlling for gender, age, head of household, direct action, and other important factors, residents of La Carpio slum are more likely to engage politically if they are involved in multiple socio-political arenas. The data appear to support the following conclusion: a small group of respondents show a tendency to engage in varying political activities which are mutually reinforcing. This conclusion appears reasonable given the relatively small proportion of respondents who indicated that they have participated in a collective association $(16 \%)$, have voted in the last two elections $(42 \%)$, or have participated in public protest $(15 \%)$. Results from logistic regression support the claim of mutual reinforcement such that engagement in one or more socio-political activities increases the odds of participation in another. In other words, if a respondent is involved in a collective association, they are significantly more likely to vote. This is not an entirely unexpected finding, yet it is one that most previous studies, by virtue of their analytical designs, have been unable to identify. These findings, taken separately may provide some guidance regarding how the poor in La Carpio engage politically.

In what follows, the author draws some isolated, limited, and somewhat speculative concluding interpretations of the findings. First, the data do reveal several positive and significant associations between social factors and specified socio-political activity. The literature has informed us that the most common form of political behavior among the poor is affiliation with neighborhood associations, community-based organizations, clientistic political arrangements, or public demonstrations. Since the "myth of marginality" was first exposed and strategies of collective consumption were proposed, the assumption has been that the urban poor engage in some forms of collective demand-making in order to achieve collective consumption (Perlman 1976; Cornelius 1975; Walton 1998). Existing literature agrees that associational life constitutes an integral element of civil society and that the democratization of Latin America creates opportunity for such privileges. Grassroots association is an elementary form of conventional politics of the disenfranchised and slum dwellers are frequently framed as networks of political activists mobilizing a grassroots social movement (Chalmers et al. 1997; Oxhorn 2003). Yet a sizeable majority of respondents in La Carpio suggest that they are disengaged individuals who operate outside the conventional institutions of associational life, where they lack institutional capacities to exert pressure. The vast majority (84\%) of respondents in La Carpio indicate that they have little experience participating in the type of civil society functions that are available to slum residents ${ }^{12}$. The few respondents who did participate in collective associations indicated that they had weak linkages to the association and experienced meager outcomes ${ }^{13}$. It was not for the lack of initiative to organize neighborhood associations in La Carpio as a large majority (71\%) indicated at least an awareness of such attempts to organize barrio residents in some forms of a collective association. Street protests are an option for the urban poor, but it has been seen that mass demonstrations are seldom mobilized by the poor because they lack legitimacy. The principal way in which the urban poor benefit from mass demonstrations is as free-riders (Villalón 2007; Blackwell 2002). Consistent with the notion that slum residents tend to avoid radical and violent behavior against the state, very few (15\%) have participated in a public demonstration (march, 
rally, and civil disobedience), civil unrest, or a strike.

Clientism offers slum residents the capacity to withhold their vote until collective demands for infrastructure improvement are met. Patronage allows the poor to exert power by threatening to withdrawal their support on which local politicians depend, unless their demands are met. Therefore, it is curious to observe that electoral behavior and attitudes of respondents are strongly indifferent. The voter participation rate among respondents in the last two elections (41\%) was significantly lower than the national average in $2010(69.11 \%)$ and in 2006 (65.13\%) (International IDEA 2013). Voter response in La Carpio is even more revealing because Costa Rica has a compulsory voting law-albeit not enforced. Void of an ongoing universal transformative project with mass support, the credibility of political parties in the mind of $\mathrm{La}$ Carpio residents is questionable. Possibly the most telling of the respondents' attitude is that a mere $19 \%$ believe that politicians can improve conditions in their barrio. Given the generalized lack of electoral participation and confidence in La Carpio, it is doubtful that these respondents would view enfranchisement as a source of empowerment (Gilbert 1998). Even if electoral participation was high, it might amount to what O’Donnell (1993: 1358) referred to as "low intensity citizenship... in which one can vote freely and have one's vote counted fairly, but cannot expect proper treatment from the police or the courts". Mistrust of the police is also common in La Carpio as $68 \%$ of respondents indicated. In spite of identifying several significant social factors that increase the odds of engaging in varying socio-political activities, the larger question is this: how do we understand the majority who do not engage in conventional socio-political activities available to slum residents and who display little confidence that bureaucracies and modern institutions can ameliorate hardships? While the urban poor are intensely interested in making material progress and improving their wellbeing, are there alternative factors in play to achieve these goals outside of the conventional political framework suggested by previous research?

Possibly Asef Bayat's concept of "quiet encroachment" may be helpful to understand how residents of La Carpio slum engage politically (Bayat 1997a; 1997b; 1998; 2000). "Quiet encroachment" was developed as a framework to understand the informal politics of urban poor societies in the slums of Iran and the Middle East. Bayat defines informality this way:

The quiet encroachment of the ordinary-a silent, patient, protracted and pervasive advancement of ordinary people on the propertied and powerful in order to survive hardships and better their lives. They are marked by quiet, atomized, and prolonged mobilization with episodic collective action-an open and fleeting struggle without clear leadership, ideology or structured organization, on which makes significant gains for the actors, eventually placing them as a counterpoint vis-à-vis the state. (Bayat 1997a: 57)

Bayat's thesis of informal politics distinguishes itself from previous analysis in that it captures the reality of social atomization resultant from neoliberal transformations. Too frequently, previous research presents the urban poor as a unified, homogeneous, and communitarian society. Since Scott's $(1985 ; 1976)$ work among a stratified but closed peasant society, researchers tend to see a "moral economy" embedded in communitarian life in many oppressed societies. However, silent encroachment captures the ambiguity of fragmented, monadic, and disaggregated lives of the urban poor and the implications for political behavior (see also Oxhorn 2009; 2003; Escobar 1992). Bayat's concept of quiet encroachment provides an alternative framework for understanding how the urban poor achieve the redistribution of goods in the form of collective consumption and co-option of public space that improves the life chances of many slum dwellers. As opposed to collective demand-making, some barrios are characterized by a repertoire of individual direct action. Direct action can 
be understood as a norm rooted in necessity that justifies the satisfaction of basic needs so long as no one is harmed in the process (Bayat 1997a: 62) ${ }^{14}$. Direct action may begin as a survival tactic but as it encompasses all spheres of life (economic, political, and cultural), it becomes the operating principle of an integrated worldview that frames the inner-logic of urban poor subjects. Direct action achieves two goals that are very important to the poor. It achieves redistribution of social goods (land, shelter, and public services) and it achieves autonomy from the state and self-determination. According to Bayat, autonomy is not only an end, but it is a means to accomplish redistribution. Therefore, autonomy and redistribution are inextricably bound. The modest levels of participation in conventional political options reflected in the data suggest that there may be something beyond eclectic household survival strategies and beyond "necessity" that explains how the poor of La Carpio understand their political behavior. Thus empirical research designed to understand how quiet encroachment is manifested among the urban poor is warranted.

Evidence presented in this study, although limited to quantitative analysis, suggests that political attitudes and behavior of a representative sample of urban poor subjects in La Carpio slum have shown that they are neither passively fatalistic nor given over to manipulation by brokerage and clientism. Neither are they explosive or revolutionary. Even the centrist position promoted by Scott (Weapons of the Weak) is mis-specified to the degree that the urban poor of $\mathrm{La}$ Carpio do more than simply survive and resist cultural hegemony which presents an image of defense and victimization. Rather, the evidence presented here warrants an exploration for an alternative framework that may explain how and why the urban poor of $\mathrm{La}$ Carpio engage in political behavior the way they do. Bayat's (1997a: 56) framework suggests that the urban poor are "surreptitiously offensive" by constructing everyday practices that improve their life chances by reallocating public space, social goods, and social capital, thus acquiring symbolic power to themselves. While survival strategies may be one of the operative motivations in their decision-making process, pragmatism is possibly overshadowed by a stronger sense of moral imperative reflected in the self-identified disclosure that "one's own direct action" is the best resolve to their immanent needs ${ }^{15}$. In moral language of urban politics, self-help housing and the informal economy articulate how the poor understand and justify their acts of transgression against dominate codes. Informality is perceived as a moral act in response to the urgency of survival and includes non-economic intangibles such as self-dignity, self-determination, and autonomy from the state. Escobar and Alvarez (1992: 320) had also suggested that a "survival struggle" over basic needs must be re-conceptualized (re-theorized) to include non-economic dimensions such as the "production of meaning" and "collective forms of cultural production". Although the urban poor are caught in a contradictory current of change, social fragmentation, and atomization-engendering chaos and instability - an individual's ability to take action during a crisis brings about empowerment, allowing the individual to feel as though they have some control in the situation. By taking direct action in order to produce stability out of social chaos creates some degree of self-efficacy. Therefore, it may be that what Bayat, Alvarez and Escobar have identified is this; what the poor really want is autonomy to construct their own culture.

\section{Conflict of Interest}

The author declares that he has no conflict of interest.

\section{Compliance With Ethical Standards}

All procedures performed in the study involving human participants were in accordance with the ethical standards of the institutional research committee. 


\section{Informed Consent}

Informed consent was obtained from all individual participants included in the study.

\section{Notes}

1. By "politics of informality", the author refers to Bayat's concept which suggests that the poor compensate for the lack of institutional power and influence, not by protest but by redress for immediate outcomes related to everyday needs - squatter housing, pirated services, and informal work - thru direct action which allows them to control their own affairs without involving the state and formal institutions; see Bayat (1997a). The concept also appears in Palmer (2003).

2. For survival, see Mainwaring (1989); for domestic demands, see Castells (1983); for distaste of confrontation, see Cornelius (1975); for gender expectations, see Neuhouser (1989; 1998); and for a repressive environment, see Adams (2012; 2013).

3. It is important to recognize that several examples of political behavior cited in this study took place in diverse political contexts - including authoritarian oppression of Pinochet in Chile (1973-1989) and the military juntas of Brazil (1964-1985) - which conditioned how the urban poor engaged politically as compared to urban poor living in societies experiencing a democratic transition (Ecuador 1979, Peru 1980, Argentina 1983, Uruguay 1984, El Salvador 1984, Guatemala 1986, Paraguay 1993, Costa Rica 1948, Colombia 1958, and Venezuela 1958) who had greater political opportunities.

4. Neither Friedmann (1989) nor Schneider (1995) explained how grassroots movements are linked to broader national party polices which would provide sustainability. Other idealistic accounts of grassroots movements include: Posner (2004) and Arias (2004). Roberts (1997) cautioned against placing too much optimism in popular organizations as harbingers of political change.

5. Alvarez (1998: 306-308) was credited with citing the "NGOization" of social movements which bring in outside funds, provide professional staff, and professionalize the grassroots effort in such a way that makes the progenitors of the group clients of an external state or organization. See Palmer (2003: 241, 248).

6. The phrase "collective consumption" generally refers to action which includes mobilization by consumers of urban services focused on the availability of public goods such as land, housing, water, electricity, and expressed by actions such as land invasions, squatter protests, and street demonstrations; see Walton (1998: 463).

7. Alvarez and colleagues are among others who display hopeful thinking in the mid-1990s that "new" social movements would be facilitators and vanguards of participatory democracy and sources of empowerment for the excluded (Alvarez, Dagnino, and Escobar 1998). Hochstetler (2012) pointed out that studies on social movements in Latin America tend to be skewed towards only reporting positive cases.

8. Some land invasions are provocative - a deliberate political act challenging the state, while other invasions are simply passive events which develop over time. See Neuhouser (1995); Aristizabal and Gómez (2004); Dosh (2006); Schneider (1988); and Castells (1983).

9. According to the Human Development Report (HDP), since 2001, Costa Rica's rank in the UN Development Program has consistently worsened. It placed 48th out of 177 countries surveyed in the 2006 index and dropped to 62nd in 2013. According to UNDP, $2.2 \%$ of Costa Ricans, or about 86,000 people, live on less than US\$ 1 a day, while $7.2 \%$, or about 322,000 people, live on less than US\$ 2 a day. See Human Development Report (New York: United Nations Development Program, UNDP, 2006, 2013).

10. Campos Cordero (2006: 49-50) found over 20 independent community-based organizations working to provide social assistance. These independent organizations tend to be focused on economic assistance, family welfare, education, and medical/dental assistance. By comparison, public entities such as ASEMECO, PANI, IMAS, MIVAH, and INA provide various levels of assistance in public health, education, and human services designed to improve the quality of life in La Carpio. In addition, some public entities have formed a partnership with the private organizations in order to extend the reach of their service (see Sandoval García 2010: 63-64).

11. The most important concern to every resident in La Carpio is the acquisition of title to the property on which they live. After 25 years of existence, not one household possesses title to the land upon which they live (Sandoval García 2010; Campos Cordero 2006). Eight years after the first settlement arrived and had managed to negotiate with state agencies to provide basic services (potable water and electricity), administrators of the same agencies (IMAS, INVU, and MIVAH) began to serve as advocates for legalizing La Carpio. This process ultimately became a political one requiring a patron-client relationship with a political party. The Partido Liberación Nacional (PLN) campaigned very hard in La Carpio (Sandoval García 2010: 362) however, it was the administration of Miguel Rodríguez Echeverría (1998-2002) of the Partido Unidad Social Cristiana (PUSC) that first formulated a plan to 
regularize land tenure in $\mathrm{La}$ Carpio. The subsequent administration (Abel Pacheco de la Esperilla 2002-2006) formed the Inter-Institutional Commission on Integration (CII) consisting of MIVAH, IMAS, INVU, the Municipalidad de San José, Ministerio de Salud Pública (MSP), and the Instituto Costarricense de Electricidad (ICE). After meeting for five sessions for the purpose of implementing a program of land entitlement, the initiative dissolved and the process was terminated (Campos Cordero 2006: 34-35; and Defensoría de los Habitantes. Expediente No. 17996-22-04. Informe Final Con Recomendaciones. 2005: 16).

12. One reason that may explain weak support for barrio associations is due to first attempts to organize barrio committees in order to pursue collective consumption: water and electricity. According to Sandoval García (2010: 44), "attempts to satisfy barrio needs were characterised by intense conflicts, disputes and tensions between residents leaving an indispensable reference for the history and memory of the community twenty years later". These observations are similar to findings cited in Mitlin (2001: 156); Burgwal (1995: 221); and Stokes (1995: 28).

13. Of the 59 respondents indicating some types of collective association involvement, only nine participated "a lot", 20 participated "a little", and 30 participated "every now and again". Likewise only 18 participants indicated that the association produced "positive outcomes" while 28 indicated "no results".

14. State processes, such as the failure to legalize land tenure (see Note \# 11) only serve to frustrate the urban poor and create cynicism towards political solutions. Furthermore, bureaucracy drives urban poor actors to find innovative ways to redistribute social goods in the form of collective consumption and public space leading to life chances that guarantee minimal living standards. Informality and direct action become functional strategies because they provide the opportunity for urban poor subjects to interpret their own needs and to shape their life conditions; see Bayat (1997a: 59-62; 2000: 545).

15. The survey asked respondents the following question: "According to your experience, which of the following do you consider to offer a real and concrete solution to the needs of your family?". The responses were "my own direct action" (90\%) as opposed to social services offered by either the state $(6 \%)$, or by community-based organizations (4\%). This along with other questions in the survey designed to measure desires for autonomy, self-determination, and self-dignity lead the author to state that there is motivation within the actions of the urban poor beyond simple survival and necessity.

\section{References}

Adams, J. 2012. Surviving Dictatorship: A Work of Visual Sociology. New York: Routledge.

- 2013. Art Against Dictatorship: Making and Exporting Arpilleras Under Pinochet. Austin, TX: University of Texas Press.

Almeida, P. 2007. "Defensive Mobilization: Popular Movements Against Economic Adjustment Policies in Latin America." Latin American Perspective 34(3):123-139.

Alvarez, S. 1998. "Latin American Feminisms Go Global." Pp. 293-324 in Cultures of Politics/Politics of Cultures: Re-visioning Latin American Social Movements, edited by S. Alvarez, E. Dagnino, and A. Escobar. Boulder, CO: Westview Press.

Alvarez, S., E. Dagnino, and A. Escobar. 1998. Cultures of Politics/Politics of Cultures: Re-visioning Latin American Social Movements. Boulder, CO: Westview Press.

Arias, D. E. 2004. "Faith in Our Neighbors: Networks and Social Order in Three Brazilian Favelas." Latin American Politics and Society 46(1):1-38.

Aristizabal, N. and A. Gómez. 2004. "Improving Security Without Titles in Bogotá." Habitat International 28(2):245-258.

Armet, S. 2005. "Controlling the Means of Production: The Urban Poor in an Age of Globalism." Culture and Religion $6(2): 309-326$.

Auyero, J. 2001. "Glocal Riots." International Sociology $16(1): 33-53$.

Barriga, M. D. 1996. "Necesidad: Notes on the Discourses of Urban Politics in the Ajusco Foothills of Mexico City." American Ethnologist 23(2):291-310.

Bayat, A. 1997a. "Un-civil Society: The Politics of the Informal People." Third World Quarterly 18(1):53-72. . 1997b. Street Politics. New York: Columbia University Press.

- 1998. "Revolution Without Movement and Movement Without Revolution: Comparing Islamic Activism in Iran and Egypt." Society for Comparative Study of Society and History 40(1):136-169.

—. 2000. "From Dangerous Classes to Quiet Rebels." International Sociology 15(3):533-557.

Blackwell, B. 2002. Micro-Politics and the Cook-Pot Revolution in Argentina. Retrieved March 7, 2013 (http://www.zcommunications.org/micropolitics-and-the-co oking-pot-revolution-in-argentina-by-benjamin-blackwell).

Burgwal, G. 1995. Struggle of the Poor: Neighborhood Organization and Clientistic Practices in a Quito Squatter Settlement. Amsterdam: CEDLA.

Campos Cordero, R. 2006. "Incidencia del Medio Social y 
Físico Sobre las Infracciones a Cuatro Leyes Nacionales en La Carpio: 2002-2004" (Incidence of the Social and Physical Environment on the Infractions to Four National Laws in La Carpio: 2002-2004). Master's thesis, Universidad de Costa Rica, San José, Costa Rica.

Cardoso, R. 1992. "Popular Movements in the Context of the Consolidation of Democracy in Brazil.” Pp. 291-303 in The Making of Social Movements in Latin America, edited by A. Escobar and S. Alvarez. Boulder, CO: Westview Press.

Castells, M. 1977. The Urban Question. London: Edward Arnold.

Castells, M. 1979. City, Class and Power. London: Edward Arnold.

- 1983. The City and the Grassroots. London: Edward Arnold.

Chalmers, D., S. Martin, and K. Piester. 1997. "Associative Networks: New Structures of Representation for the Popular Sectors?" Pp. 543-592 in The New Politics of Inequality in Latin America, edited by D. Chalmers, C. Vilas, K. Hite, S. Martin, K. Piester, and M. Segarra. Oxford: Oxford University Press.

Colburn, F. 2002. Latin America at the End of Politics. Princeton: Princeton University Press.

Cornelius, W. 1975. Politics and the Migrant Poor in Mexico City. Stanford: Stanford University Press.

Cross, J. 1998. Informal Politics. Stanford: Stanford University Press.

Dietz, H. 1998. Urban Poverty, Political Participation and the State: Lima 1970-1990. Pittsburgh: University of Pittsburgh Press.

Dosh, P. 2006. "Surprising Trends in Land Invasions in Metropolitan Lima and Quito." Latin American Perspective 33(6):29-54.

Echegaray, F. 2015. "Voting at the Marketplace." Latin American Research Review 50(2):176-199.

Eckstein, S. 1990. "Urbanization Revisited: Inner-City Slum of Hope and Squatter Settlement of Despair." World Development 18(2):165-181.

—. 2001. "Where Have All the Movements Gone?" Pp. 351-406 in Power and Popular Protest, edited by S. Eckstein and T. Crowley. Berkeley: University of California Press.

Escobar, A. 1992. "Culture, Economics and Politics." Pp. 62-88 in The Making of Social Movements in Latin America, edited by A. Escobar and S. Alvarez. Boulder, CO: Westview Press.

Escobar, A. and S. Alvarez. 1992. The Making of Social Movements in Latin America. Boulder, CO: Westview Press.

Foweraker, J. and T. Landman. 1997. Citizenship Rights and Social Movements. Oxford: Oxford University Press.
Friedmann, J. 1989. "The Latin American Barrio Movement as a Social Movement: Contribution to a Debate." Urban and Regional Research 13(3):501-510.

Garay, C. 2007. "Social Policy and Collective Action: Unemployed Workers, Community Associations, and Protest in Argentina." Politics and Society 35(2):301-328.

Gay, R. 1994. Popular Organization and Democracy in Rio de Janeiro. Philadelphia: Temple University Press.

Gilbert, A. 1998. The Latin American City. London: Latin America Bureau.

Gilbert, A. and P. Ward. 1981. "Public Intervention, Housing and Land Use in Latin American Cities." Bulletin of American Research 1(1):97-104.

- 1984. "Community Action by the Urban Poor: Democratic Involvement: Community Self-Help or Means of Social Control?" World Development 12(8):769-782.

Green, D. 1999. Silent Revolution: The Rise of Market Economics in Latin America. London: Latin American Bureau.

Hochstetler, K. 2012. "Social Movements in Latin America." Pp. 237-248 in Routledge Handbook of Latin American Politics, edited by P. Kingstone and D. Yashar. London: Routledge.

Human Development Report (HDP). 2006. International Cooperation at a Crossroads: Aid, Trade, and Security in an Unequal World. New York: United Nations Development Program (UNDP).

International IDEA (International Institute for Democracy and Electoral Assistance). 2013. Voter Turnout. Retrieved March 2013 (http://www.idea.int/vt/).

Köhler, B. and M. Wissen. 2003. "Glocalizing Protest: Urban Conflicts and Global Social Movements." International Journal of Urban and Regional Research 27(4):942-951.

Lind, A. 2005. Gendered Paradoxes: Women's Movements, State Restructuring, and Global Development in Ecuador. University Park, PA: Pennsylvania State University Press.

Lomnitz, L. 1974. "The Social and Economic Organization of a Mexican Shantytown." In Latin American Urban Research. Vol. 4, edited by W. Cornelius and F. Trueblood. Beverly Hills: Sage Publications.

Mainwaring, S. 1987. "Urban Popular Movements, Identity, and Democratization in Brazil." Comparative Political Studies 20(2):131-159.

_. 1989. "Grassroots, Popular Movements and the Struggle for Democracy: Nova Iguacu." Pp. 168-204 in Democratizing Brazil: Problems of Transition and Consolidation, edited by A. Stepan. London: Oxford Press.

Mainwaring, S. and T. Scully 1995. Building Democratic Institutions: Party Systems in Latin America. Stanford: Stanford University Press.

McAdam, D., R. Sampson, S. Weffer, and H. MacIndoe. 2005. 
"There Will Be Fighting in the Distorting Lens of Social Movement Theory." Mobilization: An International Journal 10(1):1-18.

Menard, S. 1995. Applied Logistic Regression Analysis. Thousand Oaks, CA: Sage.

Mitlin, D. 2001. "Civil Society and Urban Poverty: Examining Complexity." Environment and Urbanization 13(2):151-173.

Nemirovsky, J. 2008. "Metodología Para la Intervención de Asentamientos Informales" (Methodology for the Intervention of Informal Settlements). Unpublished master's thesis, Universidad de Costa Rica, San José, Costa Rica.

Neuhouser, K. 1989. "Sources of Women's Power and Status Among the Urban Poor in Contemporary Brazil." Signs 14(3):685-702.

—. 1995. "Worse Than Men: Gendered Mobilization in an Urban Brazilian Squatter Settlement." Gender and Society 9(1):38-59.

. 1998. "If I Had Abandoned My Children: Community Mobilization and Commitment to the Identity of Mother in Northeast Brazil." Social Forces 77(1):331-358.

O’Donnell, G. 1993. "On the State, Democratization, and Some Conceptual Problems: A Latin American View." World Development 2(8):1355-1369.

Ortner, S. 1995. "Resistance and the Problem of Ethnographic Refusal." Comparative Studies in Society and History 37(1):173-193.

Oxhorn, P. 2003. "Social Inequality, Civil Society, and the Limits of Citizenship in Latin America." Pp. 35-63 in What Justice? Whose Justice? Fighting for Fairness in Latin America, edited by S. Eckstein and T. Wickham-Crowley. Berkeley, CA: University of California Press.

—. 2009. "Beyond Neoliberalism? Latin America's New Crossroad." In Beyond Neoliberalism in Latin America, edited by J. Burdick, P. Oxhorn, and K. M. Roberts. New York: Palgrave-Macmillan.

—. 2010. "Citizenship as Consumption or Citizenship as Agency: Comparing Democratizing Reforms in Bolivia and Brazil." Sociologias 12(24):18-43.

- 2011. Sustaining Civil Society: Economic Change, Democracy, and the Social Construction of Citizenship in Latin America. University Park, PA: The Pennsylvania State University Press.

Palmer, D. S. 2003. "Citizen Responses to Conflict and Political Crisis in Peru." Pp. 233-254 in What Justice? Whose Justice? Fighting for Fairness in Latin America, edited by S. Eckstein and T. Wickham-Crowley. Berkeley, CA: University of California Press.

Perlman, J. 1976. The Myth of Marginality. Los Angeles: University of California Press.
Petras, J. 1999. The Left Strikes Back: Class Conflict in Latin America in the Age of Neoliberalism. Boulder, CO: Westview Press.

Portes, A. 1972. "Rationality in the Slum: An Essay in Interpretive Sociology." Comparative Studies in Society and History 14(3):268-286.

Posner, P. W. 2004. "Local Democracy and the Transformation of Popular Participation in Chile." Latin American Politics and Society 46(3):55-81.

Rhodes, S. D. 2003. "Progressive Pragmatism as a Governance Model." Pp. 217-232 in What Justice? Whose Justice? Fighting for Fairness in Latin America, edited by S. Eckstein and T. Wickham-Crowley. Berkeley, CA: University of California Press.

Roberts, B. R. 2005. "Citizenship, Rights, and Social Policy." Pp. 137-158 in Rethinking Development in Latin America, edited by C. H. Wood and B. R Roberts. University Park, PA: The Pennsylvania State University Press.

Roberts, K. M. 1997. "Beyond Romanticism: Social Movements and the Study of Political Change in Latin America." Latin American Research Review 32(2):137-151.

Rottenberg, S. 1993. Costa Rica and Uruguay: The Political Economy of Poverty, Equity, and Growth. Oxford: Oxford University Press.

Ruth, S. P. 2016. "Clientelism and the Utility of the Left-Right Dimension in Latin America." Latin American Politics and Society 58(1):72-97.

Sandoval García, C. 2010. Un País Fragmentado: La Carpio, La Comunidad, Cultura y Politica (A Fragmented Country. La Carpio: The Community, Culture and Politics). San José, Costa Rica: Editorial UCR.

Schild, V. 1998. "New Subjects of Rights? Women's Movements and the Construction of Citizenship in the New Democracies." Pp. 93-117 in Cultures of Politics/Politics of Cultures: Re-visioning Latin American Social Movements, edited by S. Alvarez, E. Dagnino, and A. Escobar. Boulder, CO: Westview Press.

_. 2002. "Engendering the New Social Citizenship in Chile: NGOs and Social Provisioning Under Neoliberalism." Pp. 170-203 in Gender Justice, Development, and Rights, edited by M. Molyneux and S. Razavi. Oxford: Oxford University Press.

Schneider, C. 1988. The Mobilization at the Grassroots: Shantytowns and Resistance in Authoritarian Chile. New York: The Institute of Latin-American and Iberian Studies, Colombia University.

1995. Shantytown Protest in Pinochet's Chile. Philadelphia: Temple University Press.

Scott, J. C. 1976. The Moral Economy of the Peasant: Rebellion and Subsistence in Southeast Asia. New Haven: Yale University Press. 
1985. Weapons of the Weak: Everyday Forms of Peasant Resistance. New Haven: Yale University Press.

Stokes, S. 1991. "Politics and Latin America's Urban Poor." Latin American Research Review 26(2):75-101.

. 1995. Cultures in Conflict. Los Angeles: University of California Press.

Tulchin, J. and M. Ruthenburg. 2007. Citizenship in Latin America. Boulder, CO: Lynne Rienner Publishers.

Villalón, R. 2007. "Neo-liberalism, Corruption, and Legacies of Contention." Latin American Perspectives 34(2):139-156.

Walton, J. 1998. "Urban Conflict and Social Movements in Poor Countries: Theory and Evidence of Collective Action." Journal of Urban and Regional Research 22(3):460-481.

- 2001. "Debt, Protest, and the State." Pp. 299-328 in Power and Popular Protest, edited by S. Eckstein and T. Crowley. Berkeley: University of California Press.

Walton, J. and C. Ragin. 1990. "Global and National Sources of Political Protest: Third World Responses to the Debt Crisis.” American Sociological Review 55(6):876-890.
Ward, P. 2005. "The Lack of Cursive Thinking Within Social Theory and Public Policy: Four Decades of Marginality and Rationality in the So-Called Slum." Pp. 271-296 in Rethinking Development in Latin America, edited by C. Wood and B. Roberts. University Park: The Pennsylvania State University Press.

Weyland, K. 2004a. "Critical Debates: Neoliberalism and Democracy in Latin America: A Mixed Record." Latin American Politics and Society 46(1):135-157.

. 2004b. "Threats to Latin America's Market Model." Political Science Quarterly 119(2):291-313.

\section{Bio}

Stephen Armet, Ph.D. in Sociology at the University of Notre Dame currently serving as a sociologist and research associate with PROLADES (Programa Latinoamericano de Estudios Socioreligiosos) in San José, Costa Rica; research fields: causation (etiology), deviant cases and secularization in Uruguay. 